\title{
Perioperative transfusion and the prognosis of colorectal cancer surgery: a systematic review and meta-analysis
}

\author{
Qian-Yun Pang ${ }^{1}$, Ran $A n^{1}$ and Hong-Liang Liu ${ }^{2^{*}}$ (D)
}

\begin{abstract}
Background: Perioperative transfusion can reduce the survival rate in colorectal cancer patients. The effects of transfusion on the short- and long-term prognoses are becoming intriguing.

Objective: This systematic review and meta-analysis aimed to define the effects of perioperative transfusion on the short- and long-term prognoses of colorectal cancer surgery.

Results: Thirty-six clinical observational studies, with a total of 174,036 patients, were included. Perioperative transfusion decreased overall survival (OS) (hazard ratio (HR), 0.33; 95\% confidence interval (Cl), 0.24 to $0.41 ; P<0.0001$ ) and cancerspecific survival (CSS) (HR, 0.34; 95\% Cl, 0.21 to 0.47 ; $P<0.0001)$, but had no effect on disease-free survival (DFS) (HR, 0.17; $95 \% \mathrm{Cl},-0.12$ to $0.47 ; P=0.248)$. Transfusion could increase postoperative infectious complications (RR, $1.89,95 \% \mathrm{Cl}, 1.56$ to 2.28; $P<0.0001$ ), pulmonary complications (RR, $2.01 ; 95 \% \mathrm{Cl}, 1.54$ to $2.63 ; P<0.0001)$, cardiac complications (RR, 2.20; 95\% Cl, 1.75 to 2.76; $P<0.0001$ ), anastomotic complications (RR, 1.51; 95\% Cl, 1.29 to 1.79; $P<0.0001$ ), reoperation(RR, 2. 88; 95\% Cl, 2.05 to $4.05 ; P<0.0001$ ), and general complications (RR, 1.86; $95 \% \mathrm{Cl}, 1.66$ to $2.07 ; P<0.0001)$.

Conclusion: Perioperative transfusion causes a dramatically negative effect on long-term prognosis and increases shortterm complications after colorectal cancer surgery.
\end{abstract}

Keywords: Transfusion, Colorectal cancer, Prognosis, Meta-analysis

\section{Introduction}

Patients with colorectal cancer often have accompanying anaemia or perioperative bleeding. Allogeneic transfusion becomes necessary in these cases. Some studies have found that perioperative transfusion could suppress the immune function and increase the recurrence and metastasis $[1,2]$, but others have not $[3,4]$. One recent meta-analysis showed that perioperative transfusion could decrease the survival rate and increase the incidence rates of cancer recurrence and metastasis in colorectal cancer patients [5], but in that meta-analysis, low-quality studies were included, odds ratios (ORs) were used to extract the survival data, which was not appropriate, and the effects of censored data on the results were ignored. Until now, the effects of perioperative transfusion on the short- and long-term prognoses of the patients undergoing surgery for colorectal cancer are becoming increasingly intriguing. The effects of the volume and trigger of transfusion on the prognosis are unclear. Therefore, we conducted a systematic review and meta-analysis to address these issues and attempted to define the relationships between perioperative transfusion and short- or long-term prognosis in patients undergoing colorectal cancer surgery.

* Correspondence: liuhl75@163.com

${ }^{2}$ Department of Anesthesiology, Chongqing University Cancer Hospital and Chongqing Cancer Institute and Chongqing Cancer Hospital, NO.181, Hanyu Road, Shapingba district, Chongqing 400030, China

Full list of author information is available at the end of the article

(c) The Author(s). 2019 Open Access This article is distributed under the terms of the Creative Commons Attribution 4.0 International License (http://creativecommons.org/licenses/by/4.0/), which permits unrestricted use, distribution, and reproduction in any medium, provided you give appropriate credit to the original author(s) and the source, provide a link to the Creative Commons license, and indicate if changes were made. The Creative Commons Public Domain Dedication waiver (http://creativecommons.org/publicdomain/zero/1.0/) applies to the data made available in this article, unless otherwise stated. 


\section{Methods}

We conducted our systematic review and meta-analysis in accordance with the methods recommended by the Preferred Reporting Items for Systematic Reviews and Meta-analysis (PRISMA) guidelines. There was no registered protocol.

\section{Literature search}

The PubMed, Cochrane library, and Embase databases (from January 1990 to June 2018) were searched. The reference lists of the research studies and previous meta-analysis articles were also checked to find any further eligible trials.

The key words for the electronic search strategy included intestinal, intestine, bowel, colonic, colon, rectal, rectum, colorectal, cancer, tumour, carcinoma, neoplasm, transfusion, and blood transfusion. The citations to be searched were restricted to clinical studies and were published in English, the participants of our study were patients undergoing surgery for colorectal cancer, and the intervening measure was perioperative allogeneic transfusion. The exclusion criteria were comparison between allogeneic and autogenous transfusion or comparison between autogenous transfusion and no transfusion.

\section{Outcome parameters and data collection}

The primary outcome of interest was overall survival (OS), while the secondary outcomes included disease-free survival (DFS), cancer-specific survival (CSS), and postoperative complications. OS was defined as the time from surgery to death from any cause. DFS was defined as the time from surgery to a recurrence or death from any cause. CSS was defined as the time from surgery to death from cancer recurrence or metastasis. Data were extracted and collected by two authors independently, and disagreements were resolved by discussion and consensus among all authors.

\section{Quality assessment}

The quality of publications was judged by the Newcastle-Ottawa Scale (NOS); a quality review of the data obtained from each study was performed on the basis of case selection, comparability, and outcome reporting. The highest score was 9 stars; a study with an NOS score greater than or equal to 7 stars was defined as a high-quality study, and if the NOS score was less than 7 stars, the study was excluded.

\section{Statistical analysis}

Meta-analysis was performed using Stata 12.0 software (StataCorp LP, US). The hazard ratios (HRs) with 95\% confidence intervals (CIs) were calculated for OS, DFS, and CSS, and the risk ratios (RRs) with 95\% CIs were calculated for postoperative complications. The HRs were extracted from the multivariable analysis when both univariable and multivariable analyses were available, and Engauge Digitizer 4.1 and Adobe Photoshop software were used for the extraction of HR [6]. Statistical heterogeneity was assessed using the chi-square test and $I^{2}$ statistics; $I^{2} \geq 50 \%(P \leq 0.1)$ indicated significant heterogeneity, and the random-effects model was used, and the fixed-effects model was used when $I^{2}<50 \%(P>0.1)$ [7]. Subgroup and sensitivity analyses were performed to explore the source and size of heterogeneity among studies when necessary. Publication bias was evaluated by the Egger test, and $P \geq 0.05$ represented no statistical significance in publication bias.

\section{Results}

Literature search and characteristics of eligible trials We identified 5687 potential articles: 3749 articles from PubMed, 864 articles from Cochrane library, 1036 articles from Embase, and 38 articles from other sources. Sixty relevant articles were left after initial screening and reading the titles or abstracts, and 36 clinical observational studies with a total of 174,036 patients were ultimately included [1-4, 8-39]. The details of the screening process are presented in Fig. 1. These 36 studies were conducted in different countries and were published from 1990 to 2018. The characteristics and the qualities of these studies are presented in Table 1.

\section{Results of meta-analysis}

Overall survival (OS) Data on OS were from 24 articles $[1-4,8,9,11,13,14,16,17,19,21,22,24,28-30,32-36$, 38]. The random-effects model showed that transfusion could decrease OS significantly (HR, 0.33 ; $95 \%$ CI, 0.24 to $0.41 ; I^{2}=61.9 \%$; $P<0.0001$; Fig. 2$)$. There was no significant publication bias from the Egger test $(P=0.297)$.

Seven articles $[2,8,10,13,17,38,39]$ reported the influence of transfusion volume $(>3 \mathrm{u}$ and $\leq 3 \mathrm{u}$ ) on OS. The fixed-effects model showed that OS was lower in the large transfusion volume group $(>3 \mathrm{u})$ compared with those in the small transfusion volume group $(\leq 3 \mathrm{u})$ $\left(I^{2}=46.4 \%\right.$, HR $=0.62$, 95\% CI 0.48-0.77, $\left.P<0.0001\right)$ (Fig. 3). There was no significant publication bias from the Egger test $(P=0.072)$.

Nine articles reported the trigger of transfusion. The comparison between transfusion and non-transfusion on OS was from five of these articles [8, 13, 14, 17, 32]; in the five articles, one [14] used intraoperative bleeding $>1000$ $\mathrm{ml}$ as a trigger of transfusion, and the other four articles were included in the following meta-analysis. The triggers 


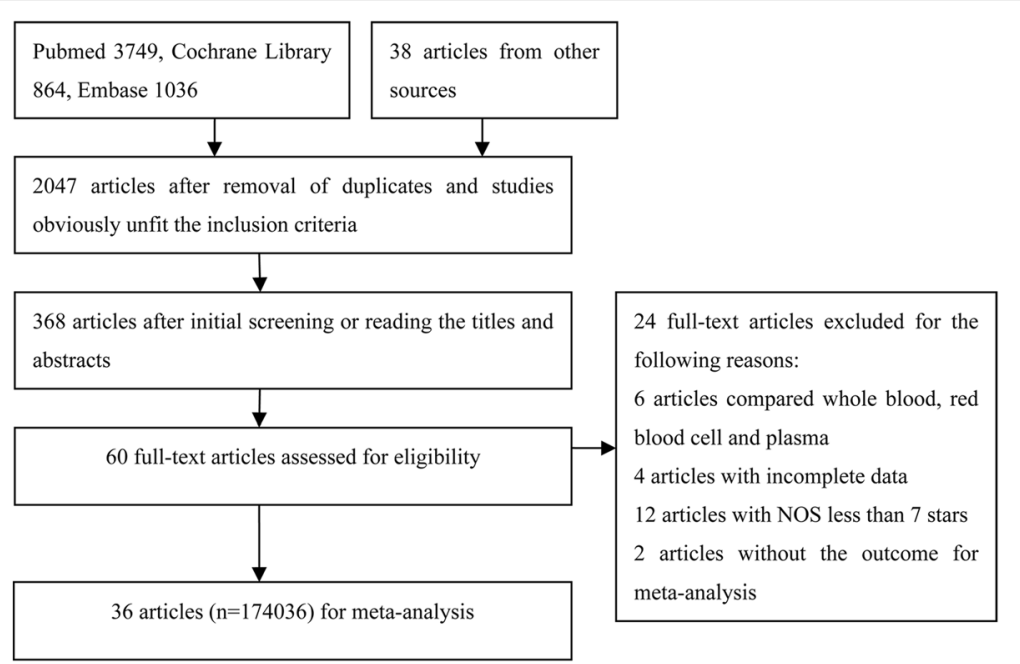

Fig. 1 Flow chart of the study screening for this meta-analysis

were $\mathrm{Hb} \leq 6 \mathrm{~g} / \mathrm{dl}$ and $\mathrm{Hb} \leq 7-10 \mathrm{~g} / \mathrm{dl}$, and the results showed that transfusion could reduce OS compared with non-transfusion if the trigger level was either $\mathrm{Hb} \leq 6 \mathrm{~g} / \mathrm{dl}$ $\left(I^{2}=0 \%, \mathrm{HR}=0.28,95 \% \mathrm{CI} 0.14-0.43, P<0.0001\right)$ or $\mathrm{Hb} \leq 7-10 \mathrm{~g} / \mathrm{dl}\left(I^{2}=0 \%, \mathrm{HR}=0.63,95 \%\right.$ CI $0.35-0.90$, $P<0.0001$ ) (Fig. 4). There was no significant publication bias from the Egger test $(P=0.667)$.

Disease-free survival (DFS) and cancer-specific survival (CSS) Data on DFS and CSS were from 7 [13, $14,19,21,32,33,37]$ and 7 articles [3, 11, 12, 14, 24, 30, 33], respectively. The random-effects model showed that transfusion could decrease CSS significantly (HR, 0.34, 95\% CI, 0.21 to $0.47, I^{2}=62.9 \% ; P<0.0001$ ) but did not affect DFS (HR, 0.17; 95\% CI, -0.12 to $0.47 ; I^{2}=54.6 \%$; $P=0.248$ ) (Fig. 5). There was no significant publication bias from the Egger test $(P=0.912)$.

Postoperative complications Data on 30- or 60-day postoperative infectious complications (wound and urinary infections), pulmonary complications (pneumonia, respiratory failure, and pulmonary embolism), cardiac complications (myocardial infarction, angina, cardiac arrest, and arrhythmia), anastomotic complications (anastomotic fistula and bleeding), reoperation, and general complications were from $9[9,13,14,16,18,23,27,28$, 31], $6[14,16,18,23,27,28], 4[14,16,18,27], 6[13,14$, $16,23,26,27], 2[11,27]$, and $10[8,10,12,13,16-18$, $20,26,27]$ articles respectively. The meta-analysis showed that transfusion could increase infectious complications (RR, 1.89, 95\% CI, 1.56 to $2.28 ; I^{2}=$ $56.2 \% ; P<0.0001$ ), pulmonary complications (RR, 2.01;
95\% CI, 1.54 to $2.63 ; I^{2}=42.4 \% ; P<0.0001$ ), cardiac complications (RR, 2.20; $95 \% \mathrm{CI}, 1.75$ to $2.76 ; I^{2}=0 \%$; $P<0.0001)$, anastomotic complications (RR, 1.51; 95\% CI, 1.29 to $\left.1.79 ; I^{2}=51.4 \% ; P<0.0001\right)$, reoperation (RR, 2.88; 95\% CI, 2.05 to $4.05 ; I^{2}=0 \% ; P<0.0001$ ), and general complications (RR, $1.86 ; 95 \% \mathrm{CI}, 1.66$ to 2.07; $I^{2}=70.4 \% ; P<0.0001$ ) (Fig. 6), and there was no significant publication bias from the Egger test $(P=0.541)$.

Subgroup and sensitivity analyses for OS Table 2 shows the subgroup analysis for OS. Publication dates, sample size, and study region did not influence the effects. However, data on OS in rectal cancer patients were only from two articles, and the subgroup analysis showed that transfusion had no significant effect on OS in rectal cancer patients, which was different from the finding for colorectal cancer or colon cancer patients. The sensitivity analysis showed that the results of the effect of transfusion on OS were not changed when any suspicious study was omitted.

\section{Discussion}

Colorectal cancer is the most common human cancer. In the past few decades, many retrospective studies have focused on the effects of perioperative transfusion on short- and long-term prognoses in colorectal cancer patients, and a larger transfusion volume seems to have a poorer prognosis. It is very important to evaluate the trigger of transfusion and the influence of the volume of transfusion on prognosis to optimise perioperative transfusion and improve the outcome in colorectal cancer patients. Our 
Table 1 Characteristics of the trials

\begin{tabular}{|c|c|c|c|c|c|c|c|c|c|}
\hline \multirow[t]{2}{*}{ ID } & \multirow[t]{2}{*}{ Country } & \multirow{2}{*}{$\begin{array}{l}\text { Tumour } \\
\text { type }\end{array}$} & \multicolumn{3}{|c|}{ Sample size } & \multirow[t]{2}{*}{ Transfusion trigger } & \multirow{2}{*}{$\begin{array}{l}\text { Type of blood } \\
\text { products }\end{array}$} & \multirow[t]{2}{*}{ Outcomes } & \multirow{2}{*}{$\begin{array}{l}\text { NOS } \\
\text { (stars) }\end{array}$} \\
\hline & & & $\overline{\mathrm{BT}+}$ & BT- & Total & & & & \\
\hline 1 Tarantino | 2013 [1] & Switzerland & Colonic & 148 & 161 & 309 & - & - & OS & 7 \\
\hline 2 Gunka I 2013 [2] & Czech & Colorectal & 132 & 451 & 583 & - & - & OS & 7 \\
\hline 3 Amri R 2017 [3] & USA & Colonic & 305 & 1118 & 1423 & - & - & OS, CSS & 8 \\
\hline $\begin{array}{l}\text { 4 Morner MEM } 2016 \\
\text { [4] }\end{array}$ & Sweden & Colorectal & 199 & 297 & 496 & - & - & OS & 8 \\
\hline 5 Qiu L 2015 [8] & China & Colorectal & 803 & 601 & 1404 & $\begin{array}{l}\mathrm{Hb}<6 \mathrm{~g} / \mathrm{dL}, \mathrm{Hb} 6-10 \mathrm{~g} / \mathrm{dL} \\
\text { according to } \\
\text { cardiopulmonary function }\end{array}$ & - & $\begin{array}{l}\text { OS, postoperative } \\
\text { complications }\end{array}$ & 7 \\
\hline 6 Miki C 2006 [9] & Japan & Colorectal & 35 & 82 & 117 & - & - & $\begin{array}{l}\text { OS, postoperative } \\
\text { complications }\end{array}$ & 8 \\
\hline 7 Meng J 2013 [10] & China & Colonic & 259 & 211 & 470 & $\mathrm{Hb}<8 \mathrm{~g} / \mathrm{dL}$ & - & $\begin{array}{l}\text { OS, postoperative } \\
\text { complications }\end{array}$ & 7 \\
\hline 8 Talukder Y 2014 [11] & Australia & Colorectal & 423 & 947 & 1370 & - & - & $\begin{array}{l}\text { OS, DFS, CSS, postoperative } \\
\text { complications }\end{array}$ & 8 \\
\hline 9 Due SL 2012 [12] & Australia & Colorectal & 151 & 654 & 805 & - & - & $\begin{array}{l}\text { CSS, postoperative } \\
\text { complications }\end{array}$ & 7 \\
\hline $\begin{array}{l}10 \text { Jagoditsch M } 2006 \\
\text { [13] }\end{array}$ & Australia & Rectal & 471 & 126 & 597 & $\begin{array}{l}\text { Preoperative } \mathrm{Hb}<8 \mathrm{~g} / \mathrm{dL} \text {, } \\
\text { intraoperative bleeding } \\
>500 \mathrm{~mL} \text { or } \mathrm{Hb}<10 \mathrm{~g} / \mathrm{dL}\end{array}$ & - & $\begin{array}{l}\text { OS, DFS, postoperative } \\
\text { complications }\end{array}$ & 7 \\
\hline $\begin{array}{l}11 \text { Lobaziewicz W } \\
2008[14]\end{array}$ & Poland & Colorectal & 122 & 135 & 257 & $\begin{array}{l}\text { Intraoperative bleeding } \\
>1000 \mathrm{~mL} \text { or } \mathrm{Hct}<30 \%\end{array}$ & $\mathrm{RBC}$ & OS, CSS, DFS & 8 \\
\hline $\begin{array}{l}\text { 12 Kaneko M } 2015 \\
{[15]}\end{array}$ & Japan & Colorectal & 23 & 85 & 108 & - & $\begin{array}{l}\text { Allogeneic red } \\
\text { blood cell }\end{array}$ & OS & 8 \\
\hline 13 Nursal TZ 2006 [16] & Turkey & Colorectal & 61 & 272 & 333 & - & Whole blood or RBC & OS & 7 \\
\hline 14 Li XX 2015 [17] & China & Colonic & 614 & 461 & 1075 & $\begin{array}{l}\mathrm{Hb}<6 \mathrm{~g} / \mathrm{dL}, \mathrm{Hb} 6-10 \mathrm{~g} / \mathrm{dL} \\
\text { according to } \\
\text { cardiopulmonary function }\end{array}$ & - & $\begin{array}{l}\text { OS, postoperative } \\
\text { complications }\end{array}$ & 7 \\
\hline 15 Halabi WJ 2013 [18] & USA & Colorectal & 3815 & 23,305 & 27,120 & - & $\mathrm{RBC}$ & $\begin{array}{l}\text { OS, postoperative } \\
\text { complications }\end{array}$ & 8 \\
\hline $\begin{array}{l}16 \text { Warschkow R } 2014 \\
\text { [19] }\end{array}$ & Switzerland & Rectal & 217 & 184 & 401 & - & $\begin{array}{l}\text { Prestored allogeneic } \\
\text { blood }\end{array}$ & OS, DFS & 7 \\
\hline 17 Koch M 2011 [20] & Germany & Colorectal & 135 & 396 & 531 & $\begin{array}{l}\mathrm{Hb} 8-10 \mathrm{~g} / \mathrm{dL} \text { according } \\
\text { to cardiopulmonary } \\
\text { function }\end{array}$ & - & Postoperative complications & 7 \\
\hline 18 Ghinea R 2013 [21] & Italy & Colorectal & 68 & 133 & 201 & - & - & $\begin{array}{l}\text { OS, DFS, postoperative } \\
\text { complications }\end{array}$ & 7 \\
\hline $\begin{array}{l}19 \text { Skanberg J } 2007 \\
\text { [22] }\end{array}$ & Sweden & Colorectal & 298 & 344 & 642 & - & LDB or $\mathrm{RBC}$ & OS & 8 \\
\hline 20 Mynster T 2000 [23] & Denmark & Colorectal & 288 & 452 & 770 & - & SAGM and/or FFP & Postoperative complications & 8 \\
\hline 21 Patel SV 2017 [24] & Canada & Colonic & 2009 & 5189 & 7198 & - & - & OS, CSS & 9 \\
\hline $\begin{array}{l}22 \text { van de Watering } \\
\text { LMG2001 [25] }\end{array}$ & Netherlands & Colorectal & 446 & 251 & 697 & - & $\mathrm{LDB}$ or $\mathrm{RBC}$ & OS & 7 \\
\hline $\begin{array}{l}23 \text { Papageorge CM } \\
2016[26]\end{array}$ & England & Colorectal & 2073 & 58,712 & 72,011 & - & Whole blood or RBC & Postoperative complications & 7 \\
\hline 24 Benoist S 2001 [27] & France & Rectal & 72 & 140 & 212 & $\mathrm{Hb}<8 \mathrm{~g} / \mathrm{dL}$ & - & Postoperative complications & 7 \\
\hline 25 Jensen LS 2005 [28] & Denmark & Colorectal & 249 & 320 & 569 & - & $\mathrm{LDB}$ or $\mathrm{RBC}$ & $\begin{array}{l}\text { OS, postoperative } \\
\text { complications }\end{array}$ & 9 \\
\hline 26 Mynster T 2001 [29] & Denmark & Colorectal & 452 & 288 & 740 & - & SAGM and/or FFP & OS & 7 \\
\hline $\begin{array}{l}27 \text { Aquina CT } 2016 \\
\text { [30] }\end{array}$ & USA & Colorectal & 6927 & 17,303 & 24,230 & - & - & $\begin{array}{l}\text { OS, CSS, postoperative } \\
\text { complications }\end{array}$ & 8 \\
\hline $\begin{array}{l}\text { 28 Mazzeffi M } 2017 \\
\text { [31] }\end{array}$ & USA & Colonic & 1845 & 23,388 & 24,733 & - & $\mathrm{RBC}$ & Postoperative complications & 8 \\
\hline $\begin{array}{l}29 \text { Van Osdol AD } 2015 \\
{[32]}\end{array}$ & USA & Colorectal & 110 & 365 & 475 & $\begin{array}{l}\text { Postoperative } \mathrm{Hb}<7 \mathrm{~g} / \mathrm{dL} \text {, } \\
\text { preoperative } \mathrm{Hb}<8.4 \mathrm{~g} / \mathrm{dL}\end{array}$ & - & $\begin{array}{l}\text { OS, DFS, postoperative } \\
\text { complications }\end{array}$ & 7 \\
\hline
\end{tabular}


Table 1 Characteristics of the trials (Continued)

\begin{tabular}{|c|c|c|c|c|c|c|c|c|c|}
\hline \multirow[t]{2}{*}{ ID } & \multirow[t]{2}{*}{ Country } & \multirow{2}{*}{$\begin{array}{l}\text { Tumour } \\
\text { type }\end{array}$} & \multicolumn{3}{|c|}{ Sample size } & \multirow[t]{2}{*}{ Transfusion trigger } & \multirow{2}{*}{$\begin{array}{l}\text { Type of blood } \\
\text { products }\end{array}$} & \multirow[t]{2}{*}{ Outcomes } & \multirow{2}{*}{$\begin{array}{l}\text { NOS } \\
\text { (stars) }\end{array}$} \\
\hline & & & $\overline{\mathrm{BT}+}$ & BT- & Total & & & & \\
\hline $\begin{array}{l}30 \text { Sánchez-Velázquez } \\
\text { P } 2018 \text { [33] }\end{array}$ & Spain & Colonic & & & 363 & - & - & DFS, CSS & 8 \\
\hline $\begin{array}{l}31 \text { Molland G } 1995 \\
\text { [34] }\end{array}$ & Australia & Colorectal & 223 & 210 & 433 & - & $\begin{array}{l}\text { All kinds of blood } \\
\text { products }\end{array}$ & OS & 8 \\
\hline $\begin{array}{l}32 \text { Cheslyn-Curtis S } \\
1990 \text { [35] }\end{array}$ & UK & Colorectal & 591 & 370 & 961 & - & - & OS & 7 \\
\hline $\begin{array}{l}33 \text { Donohue JH } 1995 \\
\text { [36] }\end{array}$ & USA & Colorectal & 446 & 605 & 1051 & - & $\begin{array}{l}\text { Whole blood or RBC } \\
\text { or plasma }\end{array}$ & OS & 8 \\
\hline 34 Tartter PI 1992 [37] & USA & Colorectal & 110 & 229 & 329 & - & RBC & DFS & 7 \\
\hline 35 Garau I 1994 [38] & Spain & Colorectal & 348 & 338 & 686 & - & $\begin{array}{l}\text { Whole blood or RBC } \\
\text { or plasma }\end{array}$ & OS & 7 \\
\hline 36 Edna TH 1994 [39] & Norway & Colorectal & 236 & 100 & 336 & $\begin{array}{l}\mathrm{Hb}<9 \mathrm{~g} / \mathrm{dL} \text { or bleeding }> \\
20 \% \text { blood volume }\end{array}$ & SAGM & OS & 8 \\
\hline
\end{tabular}

LDB leucocyte-depleted blood products, RBC packed red blood cells, SAGM buffy coat-depleted red cells suspended in saline, adenine, glucose, and mannitol, FFP fresh-frozen plasma

meta-analysis reviewed the current available literature on perioperative transfusion and the prognosis of colorectal cancer surgery and extracted the survival data by HR method, which is more precise than the OR or RR methods.
Our results showed that perioperative transfusion could reduce OS and CSS and could increase the incidence of postoperative complications. Inflammatory and immunosuppressive mediators were proved to be associated with the development of recurrence and

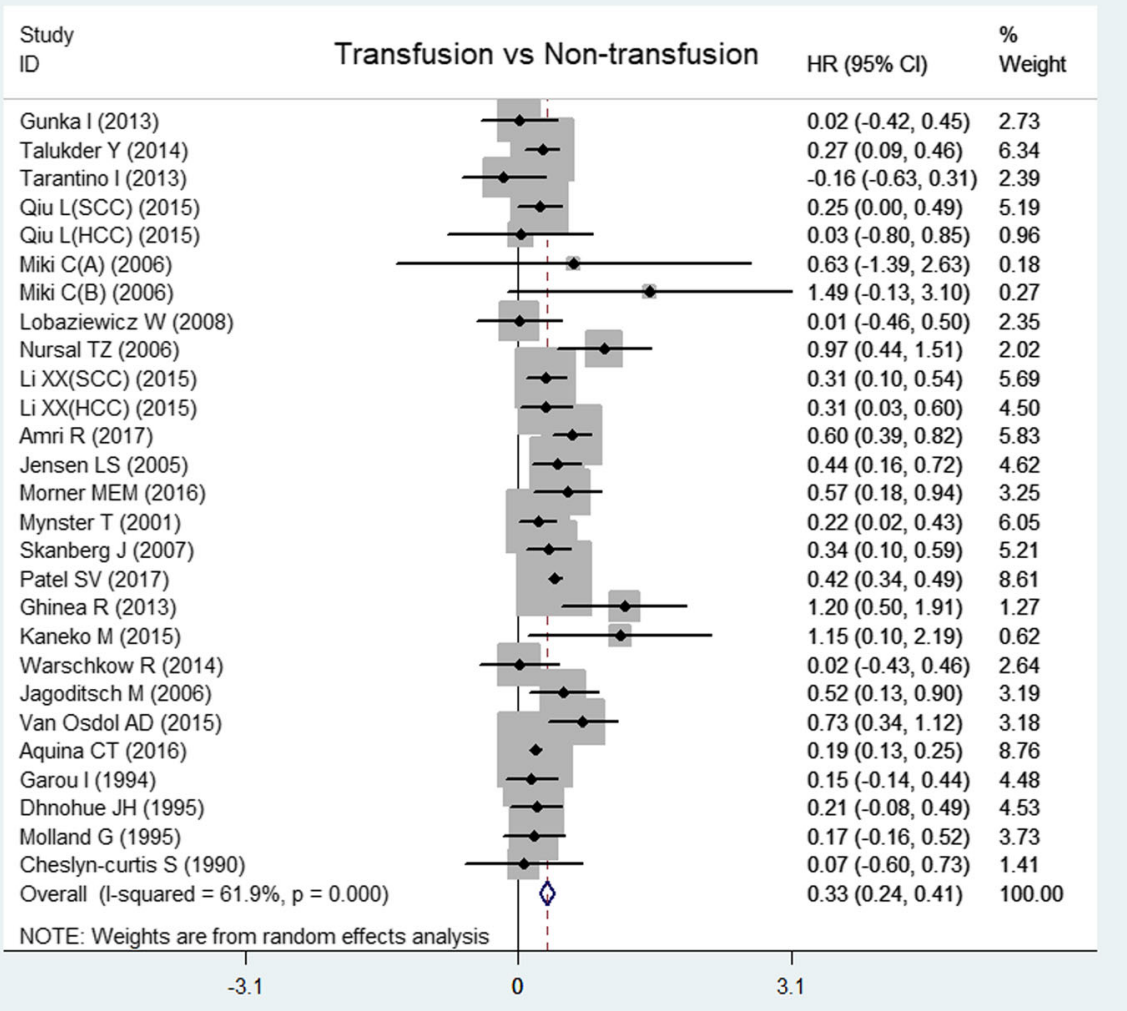

Fig. 2 Forest plot of overall survival after perioperative transfusion. SCC indicates sporadic colorectal cancer, HCC indicates hereditary colorectal cancer, group A in Miki C 2006 indicates the patient who received transfusion because of preoperative anaemia, and group B in Miki C 2006 indicates the patient who received transfusion because of excessive operative blood loss 


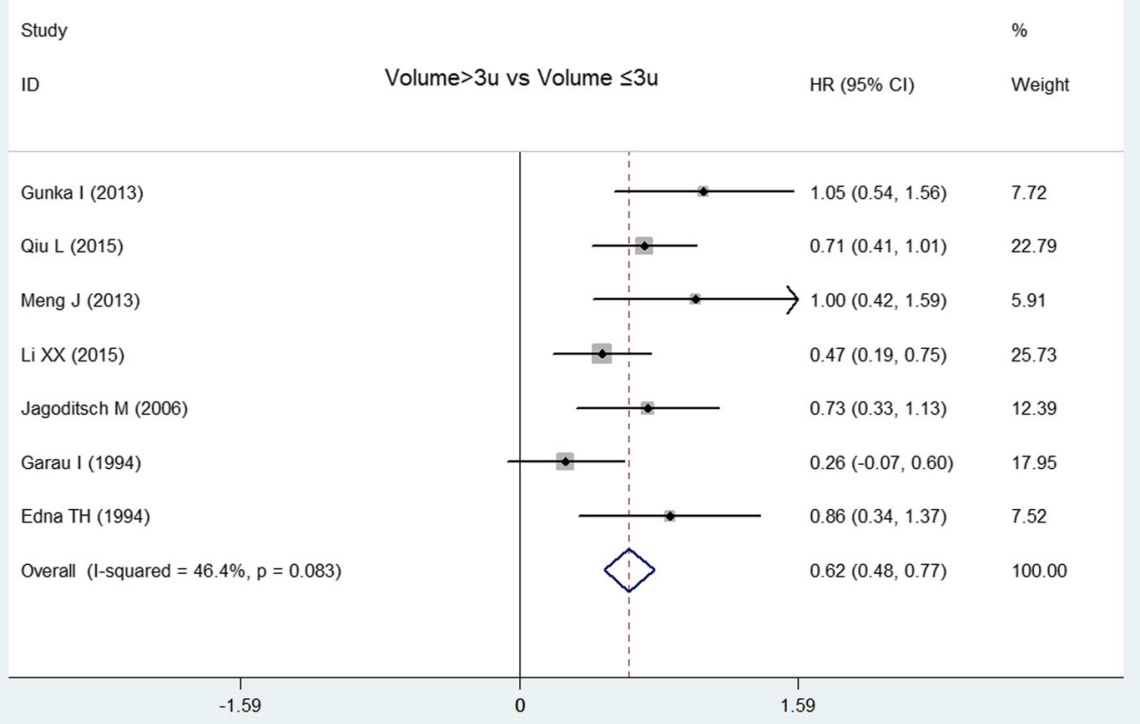

Fig. 3 Forest plot of the effect of transfusion volume on overall survival

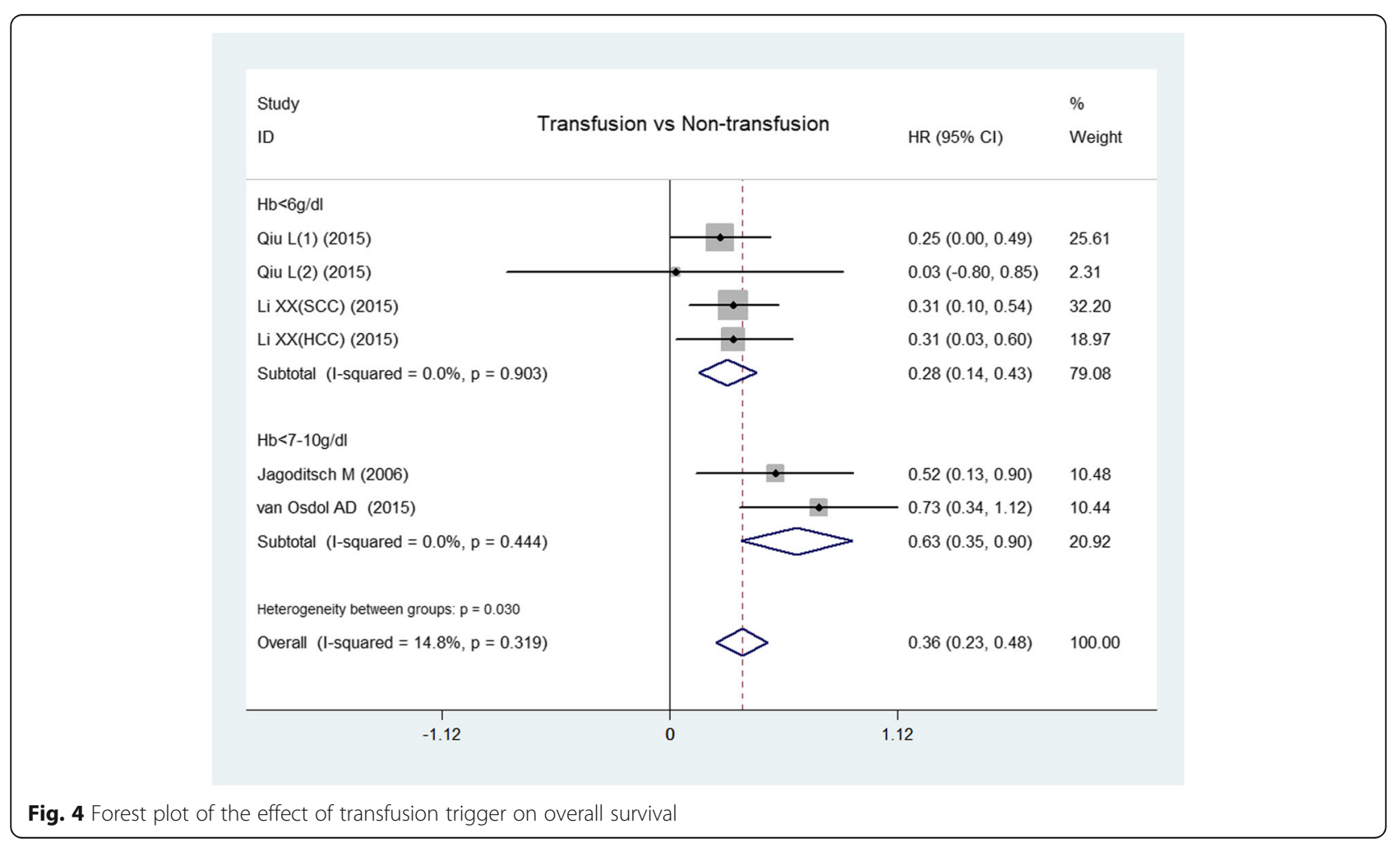




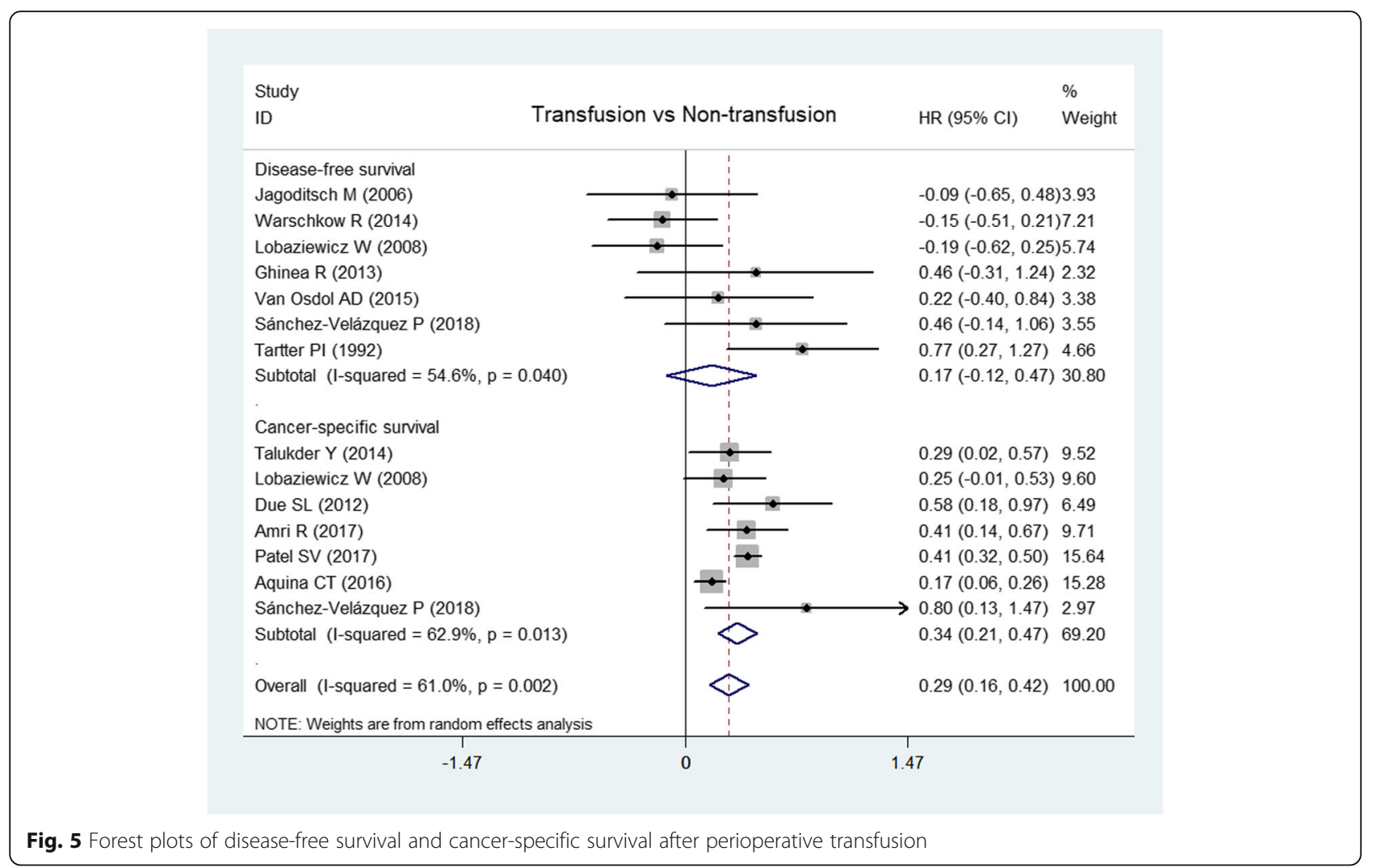

metastasis [40, 41], and transfusion could accelerate tumour progression by inducing an inflammatory response and immunosuppression [42]. In our meta-analysis, transfusion could reduce OS and CSS but had no effect on DFS. The possible reasons for this effect are that surgery, anaesthesia-related factors, and cancer staging can affect DFS, in addition to transfusion.

Allogeneic blood products release inflammatory factors during storage and can cause immunosuppression, including inhibiting NK cell activity and decreasing the Th1/Th2 ratio; eventually, infectious complications are increased after transfusion [42-46]. It has been reported that postoperative intra-abdominal infection is an independent prognostic factor of DFS and disease-specific survival in patients with colon cancer [33]. In our meta-analysis, transfusion also increased the incidence of cardiopulmonary complications, anastomotic complications, and reoperation, which suggested that postoperative complications might have a negative impact on oncologic outcome. There are only two articles (1582 patients) included that addressed the incidence of reoperation; thus, more studies are needed to confirm the result.

Our meta-analysis showed that the poor overall survival was closely related with the transfusion volume. Large amounts of blood products can generate more active biochemical substances, including vascular endothelial growth factors and plasminogen activator inhibitors, and are more likely to promote the tumour angiogenesis and tumour cell proliferation and migration [47]; together with surgical stress, large-volume transfusions may cause more immunosuppression [18]. One study showed that restrictive transfusion (transfusion trigger: $\mathrm{Hb}<8 \mathrm{~g} / \mathrm{dl}$ ) could not improve the survival rate, especially in a high-risk group of elderly patients with cardiovascular disease [48], and our meta-analysis showed that restrictive (transfusion trigger: $\mathrm{Hb} \leq 6 \mathrm{~g} / \mathrm{dl}$ ) or liberal transfusion (transfusion trigger: $\mathrm{Hb} \leq 7-10 \mathrm{~g} / \mathrm{dl}$ ) could decrease the OS significantly compared with non-transfusion. However, until now, there have been no direct comparisons between different transfusion triggers on prognosis, and very few articles report the trigger of transfusion. Since it is relatively rare in clinical circumstances that bleeding over $1000 \mathrm{ml}$ as a transfusion trigger, we performed a sensitivity analysis, and the results showed that the effect of transfusion on OS was not changed when the article was omitted. Anaemia itself could negatively affect the prognosis of malignancy and could increase the risk for overall mortality, and the presence of anaemia was an independent risk factor for postoperative complications and a longer hospital stay after colon 


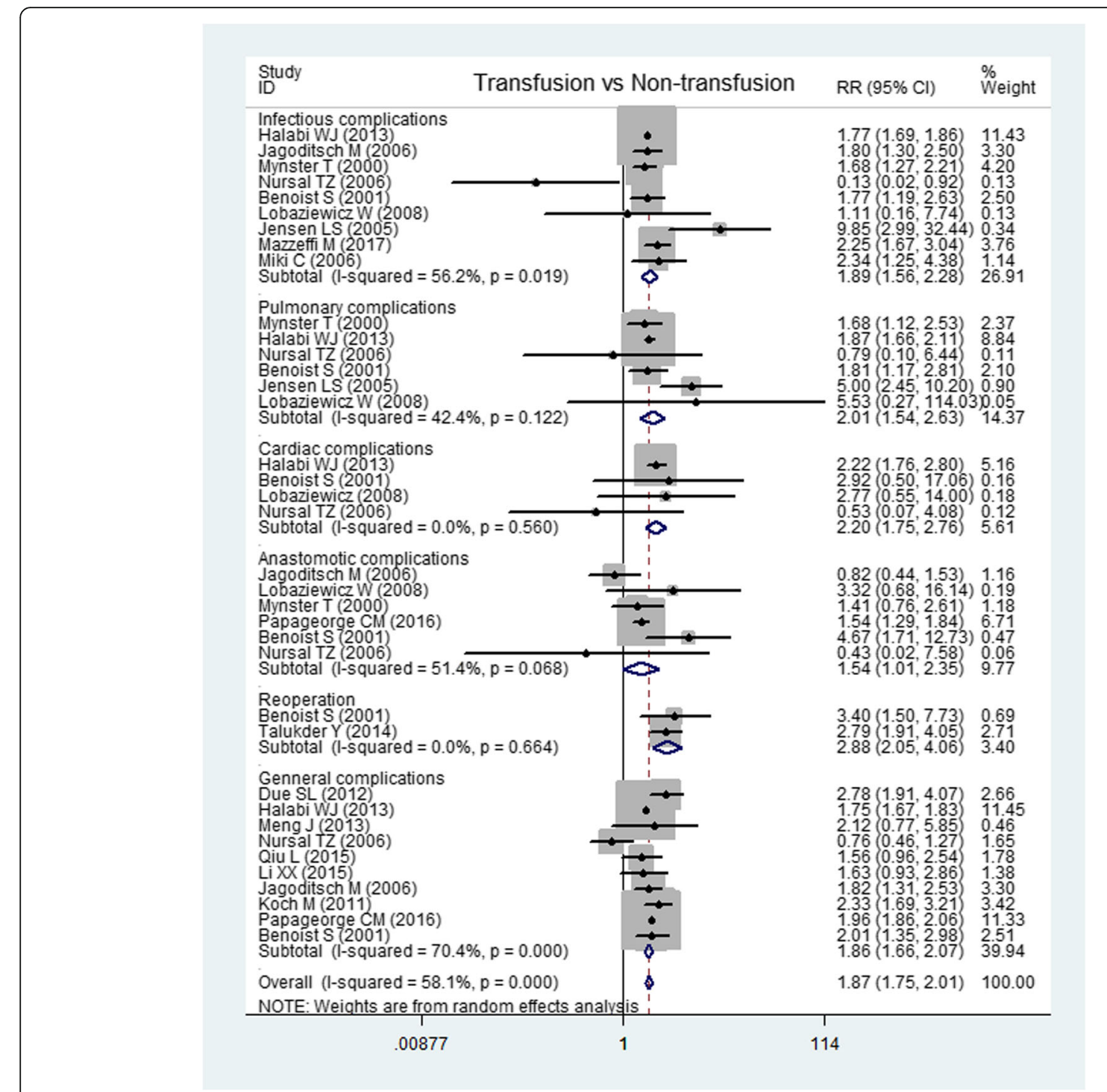

Fig. 6 Forest plots of postoperative complications after perioperative transfusion

surgery [49]; therefore, preoperative therapy for anaemia was recommend to reduce the need for blood transfusions, and iron supplements have no influence on tumour progression [50].

It is known that allogeneic transfusion can aggravate perioperative immunosuppression in cancer patients, and autogenous transfusion seems to be superior to allogeneic transfusion [51, 52], but Harlaar et al. did not find any benefit from autologous transfusion compared with allogeneic transfusion after long-term follow-up in colorectal cancer patients [53]. The clinical data for autogenous transfusion in cancer patients are sparse, and the safety of autogenous transfusion is still a big concern in the clinic, as autogenous transfusion has the potential risk to induce iatrogenic metastasis.
There are some limitations of our meta-analysis. All of the included articles were observational studies, published from 1990 to 2018. The methods and drugs for anaesthesia and analgesia were not mentioned in these trials and may be different to some extent. Some other risk factors such as preoperative $\mathrm{Hb}$ level, different kinds and storage durations of blood products, operation duration, and the staging of cancer might affect the prognosis of colorectal cancer surgery. According to the subgroup analysis, different types of surgical procedure had different outcomes. However, most of the included articles did not describe colonic and rectal cancers surgery separately, so that the articles including colon cancer or rectal cancer are taken together in our meta-analysis. Therefore, prospective controlled clinical 
Table 2 Subgroup analyses for overall survival

\begin{tabular}{lllll}
\hline Stratified & No. of studies & $P^{2}(\%)$ & $H R(95 \% \mathrm{Cl})$ & $P$ value \\
\hline $\begin{array}{l}\text { Publication date (year) } \\
1990-2000\end{array} \quad 4$ & 0 & $0.17(0,0.34)$ & 0.049 \\
$2001-2010$ & 7 & 4.5 & $0.32(0.19,0.45)$ & $<0.0001$ \\
$2011-2018$ & 14 & 74.7 & $0.37(0.25,0.48)$ & $<0.0001$ \\
Study size (no. of patients) & & & \\
$<500$ & 9 & 63.1 & $0.42(0.12,0.71)$ & 0.005 \\
$\geq 500$ & 5 & 63.1 & $0.32(0.23,0.40)$ & $<0.0001$ \\
Region & & & & \\
Asia & 4 & 0 & $0.31(0.17,0.45)$ & $<0.0001$ \\
Europe & 12 & 56.9 & $0.29(0.12,0.46)$ & 0.0001 \\
America & 5 & 88.7 & $0.40(0.22,0.57)$ & $<0.0001$ \\
Australia & 3 & 0 & $0.29(0.14,0.44)$ & $<0.0001$ \\
Surgical type & & & & $<0.0001$ \\
Colorectal & 18 & 48.6 & $0.31(0.21,0.41)$ & $<0.0001$ \\
Colonic & 4 & 59.8 & $0.37(0.23,0.52)$ & 0.258 \\
Rectal & 2 & 63.8 & $0.28(-0.21,-0.77)$ & \\
\hline
\end{tabular}

No. number, $H R$ hazard ratio, 95\% Cl 95\% confidence interval

trials with large sample sizes need to be conducted to verify the results of our meta-analysis.

\section{Conclusion}

The results of our meta-analysis suggest that perioperative transfusion causes a dramatically negative effect on long-term prognosis and increases the short-term complications after colorectal cancer surgery.

\section{Abbreviations}

CSS: Cancer-specific survival; DFS: Disease-free survival; OS: Overall survival

\section{Acknowledgements}

The authors declare that no acknowledgements have to be made.

\section{Funding}

Not applicable.

\section{Availability of data and materials}

The datasets supporting the conclusion are included in the article.

\begin{abstract}
Authors' contributions
H-LL participated in the design of the study, revised the manuscript, and edited the language. Q-YP collected the data, performed the statistical analysis, and drafted the manuscript. RA collected the data and revised and proofread the manuscript. All authors read and approved the final manuscript.
\end{abstract}

\section{Ethics approval and consent to participate}

Not applicable.

\section{Consent for publication}

Not applicable.

\section{Competing interests}

The authors declare that they have no competing interests.

\section{Publisher's Note}

Springer Nature remains neutral with regard to jurisdictional claims in published maps and institutional affiliations.

\section{Author details}

'Chongqing University Cancer Hospital and Chongqing Cancer Institute and Chongqing Cancer Hospital, Chongqing, China. ${ }^{2}$ Department of Anesthesiology, Chongqing University Cancer Hospital and Chongqing Cancer Institute and Chongqing Cancer Hospital, NO.181, Hanyu Road, Shapingba district, Chongqing 400030, China.

Received: 30 August 2018 Accepted: 23 December 2018

Published online: 05 January 2019

\section{References}

1. Tarantino I, Ukegjini K, Warschkow R, Schmied BM, Steffen T, Ulrich A, et al. Blood transfusion does not adversely affect survival after elective colon cancer resection: a propensity score analysis. Langenbeck's Arch Surg. 2013; 398(6):841-9. https://doi.org/10.1007/s00423-013-1098-x PubMed PMID: 23838797.

2. Gunka I, Dostalik J, Martinek L, Gunkova P, Mazur M. Impact of blood transfusions on survival and recurrence in colorectal cancer surgery. Indian J Surg. 2013;75(2):94-101. https://doi.org/10.1007/s12262-012-0427-6 PubMed PMID: 24426401; PubMed Central PMCID: PMC3644148.

3. Amri R, Dinaux AM, Leijssen LGJ, Kunitake H, Bordeianou LG, Berger DL. Do packed red blood cell transfusions really worsen oncologic outcomes in colon cancer? Surgery. 2017;162(3):586-91. https://doi.org/10.1016/j.surg. 2017.03.024 PubMed PMID: 28606725.

4. Morner ME, Edgren G, Martling A, Gunnarsson U, Egenvall M. Preoperative anaemia and perioperative red blood cell transfusion as prognostic factors for recurrence and mortality in colorectal cancer-a Swedish cohort study. Int J Color Dis. 2017;32(2):223-32. https://doi.org/10.1007/s00384-016-2678-3 PubMed PMID: 27770250; PubMed Central PMCID: PMC5285411.

5. Acheson AG, Brookes MJ, Spahn DR. Effects of allogeneic red blood cell transfusions on clinical outcomes in patients undergoing colorectal cancer surgery: a systematic review and meta-analysis. Ann Surg. 2012;256(2):235-44. https://doi.org/10.1097/SLA.0b013e31825b35d5 PubMed PMID: 22791100.

6. Tierney JF, Stewart LA, Ghersi D, Burdett S, Sydes MR. Practical methods for incorporating summary time-to-event data into meta-analysis. Trials. 2007;8:1.

7. Higgins JP, Thompson SG. Quantifying heterogeneity in a meta-analysis. Stat Med. 2002;21(11):1539-58. https://doi.org/10.1002/sim.1186 PubMed PMID: 12111919

8. Qiu L, Wang DR, Zhang XY, Gao S, Li XX, Sun GP, et al. Impact of perioperative blood transfusion on immune function and prognosis in colorectal cancer patients. Transfus Apher Sci. 2016;54(2):235-41. https://doi. org/10.1016/j.transci.2015.07.004 PubMed PMID: 26780991.

9. Miki C, Hiro J, Ojima E, Inoue Y, Mohri Y, Kusunoki M. Perioperative allogeneic blood transfusion, the related cytokine response and long-term survival after potentially curative resection of colorectal cancer. Clin Oncol (R Coll Radiol). 2006;18(1):60-6 PubMed PMID: 16477921; PubMed Central PMCID: PMC16477921.

10. Meng J, Lu XB, Tang YX, Sun GP, Li X, Yan YF, et al. Effects of allogeneic blood transfusion in patients with stage II colon cancer. Asian Pac J Cancer Prev. 2013;14(1):347-50 PubMed PMID: 23534751; PubMed Central PMCID: PMC23534751.

11. Talukder Y, Stillwell AP, Siu SK, Ho YH. Comparing survival and recurrence in curative stage I to III colorectal cancer in transfused and nontransfused patients. Int Surg. 2014;99(1):8-16. https://doi.org/10.9738/INTSURG-D-1300141.1 PubMed PMID: 24444262; PubMed Central PMCID: PMC3897348.

12. Due SL, Wattchow DA, Sweeney JL, Milliken L, Luke CG. Colorectal cancer surgery 2000-2008: evaluation of a prospective database. ANZ J Surg. 2012; 82(6):412-9. https://doi.org/10.1111/j.1445-2197.2012.06078.x PubMed PMID: 22537147.

13. Jagoditsch M, Pozgainer P, Klingler A, Tschmelitsch J. Impact of blood transfusions on recurrence and survival after rectal cancer surgery. Dis Colon Rectum. 2006;49(8):1116-30. https://doi.org/10.1007/s10350-006-05737 PubMed PMID: 16779711.

14. Lobaziewicz W, Kolodziejski L. The impact of homologous packed red blood cell transfusion on patients' survival after radical surgical treatment of colorectal cancer. Acta Chir Belg. 2008;108(5):524-31 PubMed Central PMCID: PMC19051460.

15. Kaneko M, Sasaki S, Ishimaru K, Terai E, Nakayama H, Watanabe T. The impact of perioperative allogeneic blood transfusion on survival in elderly patients with colorectal cancer. Anticancer Res. 2015;35(6):3553-8 PubMed PMID: 26026124; PubMed Central PMCID: PMC 26026124. 
16. Nursal TZ, Hamaloglu E. The effect of preoperative blood transfusion on morbidity and survival in colorectal malignancy. The Turkish journal of gastroenterology. Turk J Gastroenterol. 2006;17(4):283-7 PubMed Central PMCID: PMC 17205407

17. Li XX, Meng J, Sun GP, Tang YX, Liang GF, Wang MF, et al. Effects of perioperative blood transfusion on the prognosis in hereditary and sporadic colon cancer. Biomarkers. 2015;20(6-7):481-6. https://doi.org/10.3109/ 1354750X.2015.1096306 PubMed PMID: 26616149.

18. Halabi WJ, Jafari MD, Nguyen VQ, Carmichael JC, Mills S, Pigazzi A, et al. Blood transfusions in colorectal cancer surgery: incidence, outcomes, and predictive factors: an American College of Surgeons National Surgical Quality Improvement Program analysis. Am J Surg. 2013;206(6):1024-32. https://doi. org/10.1016/j.amjsurg.2013.10.001 discussion 32-3. PubMed PMID: 24296103.

19. Warschkow R, Guller U, Koberle D, Muller SA, Steffen T, Thurnheer M, et al. Perioperative blood transfusions do not impact overall and disease-free survival after curative rectal cancer resection: a propensity score analysis. Ann Surg. 2014;259(1):131-8. https://doi.org/10.1097/SLA.0b013e318287ab4d PubMed PMID: 23470578

20. Koch M, Antolovic D, Reissfelder C, Rahbari NN, Holoch J, Michalski I, et al. Leucocyte-depleted blood transfusion is an independent predictor of surgical morbidity in patients undergoing elective colon cancer surgery-a single-center analysis of 531 patients. Ann Surg Oncol. 2011;18(5):1404-11. https://doi.org/10.1245/s10434-010-1453-x PubMed PMID: 21153884

21. Ghinea R, Greenberg R, White I, Sacham-Shmueli E, Mahagna H, Avital S. Perioperative blood transfusion in cancer patients undergoing laparoscopic colorectal resection: risk factors and impact on survival. Tech Coloproctol. 2013;17(5):549-54. https://doi.org/10.1007/s10151-013-1014-y PubMed PMID: 23605190

22. Skanberg J, Lundholm K, Haglind E. Effects of blood transfusion with leucocyte depletion on length of hospital stay, respiratory assistance and survival after curative surgery for colorectal cancer. Acta Oncol. 2007;46(8):1123-30. https:// doi.org/10.1080/02841860701441830 PubMed PMID: 17851860.

23. Mynster T, Christensen IJ, Moesgaard F, Nielsen HJ. Effects of the combination of blood transfusion and postoperative infectious complications on prognosis after surgery for colorectal cancer. Danish RANX05 Colorectal Cancer Study Group. Br J Surg. 2000;87(11):1553-62. https://doi.org/10.1046/j.1365-2168.2000.01570.x PubMed PMID: 11091245.

24. Patel SV, Brennan KE, Nanji S, Karim S, Merchant S, Booth CM. Peri-operative blood transfusion for resected colon cancer: practice patterns and outcomes in a population-based study. Cancer Epidemiol. 2017;51:35-40. https://doi.org/10.1016/j.canep.2017.10.006 PubMed PMID: 29032319.

25. van de Watering LM, Brand A, Houbiers JG, Klein Kranenbarg WM, Hermans $J$, van de Velde $C$, et al. Perioperative blood transfusions, with or without allogeneic leucocytes, relate to survival, not to cancer recurrence. $\mathrm{Br} J$ Surg. 2001;88(2):267-72. https://doi.org/10.1046/j.1365-2168.2001.01674.x PubMed PMID: 11167879

26. Papageorge CM, Kennedy GD, Carchman EH. Preoperative blood transfusion is a predictor of worse short-term postoperative outcomes after colectomy. Surgery. 2017;161(4):1067-75. https://doi.org/10.1016/j.surg.2016.08.042 PubMed PMID: 27838105; PubMed Central PMCID: PMC5933528.

27. Benoist $S$, Panis $Y$, Pannegeon $V$, Alves A, Valleur P. Predictive factors for perioperative blood transfusions in rectal resection for cancer: a multivariate analysis of a group of 212 patients. Surgery. 2001;129(4):433-9. https://doi. org/10.1067/msy.2001.112068 PubMed PMID: 11283534.

28. Jensen LS, Puho E, Pedersen L, Mortensen FV, Sorensen HT. Long-term survival after colorectal surgery associated with buffy-coat-poor and leucocyte-depleted blood transfusion: a follow-up study. Lancet. 2005; 365(9460):681-2. https://doi.org/10.1016/S0140-6736(05)17949-5 PubMed PMID: 15721474

29. Mynster T, Nielsen HJ. Danish RANX05 Colorectal Cancer Study Group. Storage time of transfused blood and disease recurrence after colorectal cancer surgery. Dis Colon Rectum. 2001;44(7):955-64 PubMed PMID: 11496075; PubMed Central PMCID: PMC11496075.

30. Aquina CT, Blumberg N, Becerra AZ, Boscoe FP, Schymura MJ, Noyes K, et al. Association among blood transfusion, sepsis, and decreased long-term survival after colon cancer resection. Ann Surg. 2017:266(2):311-7. https:// doi.org/10.1097/SLA.0000000000001990 PubMed PMID: 27631770.

31. Mazzeffi M, Tanaka K, Galvagno S. Red blood cell transfusion and surgical site infection after colon resection surgery: a cohort study. Anesth Analg. 2017:125(4):1316-21. https://doi.org/10.1213/ANE.0000000000002099 PubMed PMID: 28504993.
32. Van Osdol AD, Borgert AJ, Kallies KJ, Froman JP, Bottner WA, Shapiro SB. Long-term outcomes of an integrated transfusion reduction initiative in patients undergoing resection for colorectal cancer. Am J Surg. 2015;210(6): 990-4. https://doi.org/10.1016/j.amjsurg.2015.06.026 discussion 5.PubMed PMID: 26455522

33. Sanchez-Velazquez $P$, Pera M, Jimenez-Toscano M, Mayol X, Roges $X$, Lorente $L$, et al. Postoperative intra-abdominal infection is an independent prognostic factor of disease-free survival and disease-specific survival in patients with stage II colon cancer. Clin Transl Oncol. 2018. https://doi.org/ 10.1007/s12094-018-1866-8 PubMed PMID: 29623587.

34. Molland G, Dent OF, Chapuis PH, Bokey EL, Nicholls M, Newland RC Transfusion does not influence patient survival after resection of colorectal cancer. Aust N Z J Surg. 1995;65:592-5 PubMed Central PMCID: PMC7661803.

35. Cheslyn-Curtis S, Fielding LP, Hittinger R, Fry JS, Phillips RK. Large bowel cancer: the effect of perioperative blood transfusion on outcome. Ann R Coll Surg Engl. 1990;72(1):53-9 PubMed PMID: 2405765; PubMed Central PMCID: PMC2499079.

36. Donohue JH, Williams S, Cha S, Windschitl HE, Witzig TE, Nelson $\mathrm{H}$, et al. Perioperative blood transfusions do not affect disease recurrence of patients undergoing curative resection of colorectal carcinoma: a Mayo/North Central Cancer Treatment Group study. J Clin Oncol. 1995;13(7):1671-8. https://doi.org/10.1200/JCO.1995.13.7.1671 PubMed PMID: 7602357.

37. Tratter PI. The association of perioperative blood transfusion with colorectal cancer recurrence. Ann Surg. 1992;216:633-8 PubMed Central PMCID: PMC1466616.

38. Garau I, Benito E, Bosch FX, et al. Blood transfusion has no effect on colorectal cancer survival. A Population-based Study Eur J Cancer. 1994;30A: 759-64 PubMed Central PMCID: PMC7917533.

39. Edna TH, Bjerkeset T. Perioperative blood transfusions reduce long-term survival following surgery for colorectal cancer. Dis Colon Rectum. 1998; 41(4):451-9 PubMed PMID: 9559629.

40. Pages F, Berger A, Camus M, Sanchez-Cabo F, Costes A, Molidor R, et al. Effector memory T cells, early metastasis, and survival in colorectal cancer. N Engl J Med. 2005;353(25):2654-66. https://doi.org/10.1056/NEJMoa051424 PubMed PMID: 16371631.

41. Galon J, Costes A, Sanchez-Cabo F, Kirilovsky A, Mlecnik B, Lagorce-Pages C, et al. Type, density, and location of immune cells within human colorectal tumors predict clinical outcome. Science. 2006;313(5795):1960-4. https://doi. org/10.1126/science.1129139 PubMed PMID: 17008531.

42. Cata JP, Wang H, Gottumukkala V, Reuben J, Sessler DI. Inflammatory response, immunosuppression, and cancer recurrence after perioperative blood transfusions. Br J Anaesth. 2013;110(5):690-701. https://doi.org/10.1093/bja/ aet068 PubMed PMID: 23599512; PubMed Central PMCID: PMC3630286.

43. Atzil S, Arad M, Glasner A, Abiri N, Avraham R, Greenfeld K, et al. Blood transfusion promotes cancer progression: a critical role for aged erythrocytes. Anesthesiology. 2008;109(6):989-97. https://doi.org/10.1097/ALN.0b013e31818ddb72 PubMed PMID: 19034095; PubMed Central PMCID: PMC2694914.

44. Jensen LS, Andersen AJ, Christiansen PM, Hokland P, Juhl CO, Madsen G, et al. Postoperative infection and natural killer cell function following blood transfusion in patients undergoing elective colorectal surgery. Br J Surg. 1992;79(6):513-6 PubMed PMID: 1611441.

45. Patel HB, Nasir FA, Nash GF, Scully MF, Kakkar AK. Enhanced angiogenesis following allogeneic blood transfusion. Clin Lab Haematol. 2004;26(2):129-35. https://doi.org/10.1111/j.1365-2257.2004.00589x PubMed PMID: 15053807.

46. Ben-Eliyahu S. The promotion of tumor metastasis by surgery and stress: immunological basis and implications for psychoneuroimmunology. Brain Behav Immun. 2003;17(Suppl 1):S27-36 PubMed Central PMCID: PMC12615183.

47. Horowitz M, Neeman E, Sharon E, Ben-Eliyahu S. Exploiting the critical perioperative period to improve long-term cancer outcomes. Nat Rev Clin Oncol. 2015;12(4):213-26. https://doi.org/10.1038/nrclinonc.2014.224 PubMed PMID: 25601442; PubMed Central PMCID: PMC5497123.

48. Carson JL, Sieber F, Cook DR, Hoover DR, Noveck H, Chaitman BR, et al. Liberal versus restrictive blood transfusion strategy: 3-year survival and cause of death results from the FOCUS randomised controlled trial. Lancet. 2015:385(9974):1183-9. https://doi.org/10.1016/S0140-6736(14)62286-8 PubMed PMID: 25499165; PubMed Central PMCID: PMC4498804.

49. Leichtle SW, Mouawad NJ, Lampman R, Singal B, Cleary RK. Does preoperative anemia adversely affect colon and rectal surgery outcomes? J Am Coll Surg. 2011;212(2):187-94. https://doi.org/10.1016/j.jamcollsurg.2010. 09.013 PubMed PMID: 21276532. 
50. Glechner A, Gartlehner G, Nussbaumer B, Kozek-Langenecker S.

Perioperative anemia management: a systematic review and meta-analysis. Wien Med Wochenschr. 2014;164(15-16):330-41. https://doi.org/10.1007/ s10354-014-0293-x PubMed PMID: 25168917.

51. Chen G, Zhang FJ, Gong M, Yan M. Effect of perioperative autologous versus allogeneic blood transfusion on the immune system in gastric cancer patients. J Zhejiang Univ Sci B. 2007;8(8):560-5. https://doi.org/10.1631/jzus. 2007.B0560 PubMed PMID: 17657857; PubMed Central PMCID: PMC1934950.

52. Xing YL, Wang YC. Influence of autologous and homologous blood transfusion on interleukins and tumor necrosis factor-alpha in peri-operative patients with esophageal cancer. Asian Pacific journal of cancer prevention. Asian Pac J Cancer Prev. 2014;15(18):7831-4 PubMed Central PMCID: PMC25292072.

53. Harlaar JJ, Gosselink MP, Hop WC, Lange JF, Busch OR, Jeekel H. Blood transfusions and prognosis in colorectal cancer: long-term results of a randomized controlled trial. Ann Surg. 2012;256(5):681-6. https://doi.org/10. 1097/SLA.0b013e318271cedf discussion 6-7e. PubMed PMID: 23095610.

Ready to submit your research? Choose BMC and benefit from:

- fast, convenient online submission

- thorough peer review by experienced researchers in your field

- rapid publication on acceptance

- support for research data, including large and complex data types

- gold Open Access which fosters wider collaboration and increased citations

- maximum visibility for your research: over $100 \mathrm{M}$ website views per year

At BMC, research is always in progress.

Learn more biomedcentral.com/submissions 